August 2008

\title{
The Injustice of Local Justice: Truth, Reconciliation, and Revenge in Rwanda
}

Jennie E. Burnet

Follow this and additional works at: https://digitalcommons.usf.edu/gsp

\section{Recommended Citation}

Burnet, Jennie E. (2008) "The Injustice of Local Justice: Truth, Reconciliation, and Revenge in Rwanda," Genocide Studies and Prevention: An International Journal: Vol. 3: Iss. 2: Article 4.

Available at: https://digitalcommons.usf.edu/gsp/vol3/iss2/4

This Articles is brought to you for free and open access by the Open Access Journals at Digital Commons @ University of South Florida. It has been accepted for inclusion in Genocide Studies and Prevention: An International Journal by an authorized editor of Digital Commons @ University of South Florida. For more information, please contact digitalcommons@usf.edu. 


\title{
The Injustice of Local Justice: Truth, Reconciliation, and Revenge in Rwanda
}

\author{
Jennie E. Burnet \\ Department of Anthropology, University of Louisville, Kentucky
}

\begin{abstract}
Based on long-term fieldwork in urban and rural Rwanda between 1997 and 2002 as well as on recent focus groups and interviews conducted in May and June 2007, this article explores local perceptions of the Gacaca process and asks whether Gacaca is fulfilling its primary goals to "end impunity," promote reconciliation, and establish, in the words of Paul Kagame, the "real truth of what happened during the Genocide." The findings indicate that how well Gacaca is functioning varies a great deal from community to community. The most important variable appears to be the character of the inyangamugayo ("persons of integrity") who serve as both judge and jury in the Gacaca system. Regardless of how well Gacaca is operating, in communities where research was conducted, the process has increased conflict in local communities (or at least brought it to the surface) and intensified ethnic cleavages in the short term. Since the Gacaca process began its pilot phase in 2001, community-based organizations that had reestablished or built new crossethnic relationships have faced extreme difficulties as other people (both Tutsi and Hutu) within the community have tried to destroy solidarity across ethnic lines. Increasing ethnic cleavages in the short term would not necessarily be a negative outcome if the long-term prospects for building a peaceful society were good. Unfortunately, given local perceptions of widespread injustice in the Gacaca process, the latter is not the case.
\end{abstract}

Keywords: Rwanda, genocide, reconciliation, transitional justice, local justice

The goal of the gacacas was not to parade people before the courts for form, but to try them well! (Benoit Kaboyi, executive secretary of Ibuka, the National Genocide Survivors' Association)

... the inyangamugayo won't stop until all the educated Hutu are in prison with long sentences. (Woman from Northern province, May 2007)

Fourteen years after the 1994 genocide in Rwanda, many genocide survivors and victims are still awaiting justice, although justice has been sought through a plurality of mechanisms: an ad hoc international tribunal, foreign courts, the Rwandan justice system, and a local justice mechanism known as Gacaca. In a radical departure from precedents in other post-conflict countries, where amnesties, truth commissions, selective prosecutions, or some combination thereof have been used to bring closure to conflict, Rwanda decided to put "most of the nation on trial." ${ }^{1}$ To accomplish this task, the government reinvented a "traditional" conflict-resolution mechanism known as gacaca. ${ }^{2}$ Beginning with a pilot phase in 2001 and a nationwide roll-out in 2005 , the entire population has been enlisted to prosecute, defend, testify, and judge an estimated 761,000 suspects who stood accused of genocide as of March 2005 and to hear a total of 1.1 million cases. ${ }^{3}$

Jennie E. Burnet, "The Injustice of Local Justice: Truth, Reconciliation, and Revenge in Rwanda." Genocide Studies and Prevention 3, 2 (August 2008): 173-193. (C) 2008 Genocide Studies and Prevention. doi:10.3138/gsp.3.2.173 
Based on long-term fieldwork in urban and rural Rwanda between 1997 and 2002 as well as on recent focus groups and interviews conducted in May and June 2007, this article explores local perceptions of the Gacaca process and asks whether Gacaca is fulfilling its primary goals to "end impunity," promote reconciliation, and establish the "real truth of what happened during the Genocide." $\mathrm{My}$ findings indicate that how well Gacaca is functioning varies a great deal from community to community. The most important variable appears to be the character of the inyangamugayo ("persons of integrity") who serve as both judge and jury in the Gacaca system. Regardless of how well Gacaca is operating in communities where research was conducted in 2007, the process has increased conflict in local communities (or, at least, brought that conflict to the surface) and has intensified ethnic cleavages in the short term. Since the Gacaca process began in its pilot phase in 2001, community-based organizations that had reestablished cross-ethnic relationships or built new ones have faced extreme difficulties as other people (both Tutsi and Hutu) ${ }^{5}$ within the community try to destroy solidarity that crosses ethnic lines. Increasing ethnic cleavages in the short term is not necessarily a negative outcome if the long-term prospects for building a peaceful society are good. Unfortunately, given local perceptions of widespread injustice in the Gacaca process, the long-term prospects for a peaceful and just society in Rwanda are not favorable.

\section{The Move toward Local Justice}

Since 1994, many justice mechanisms have been used to prosecute the planners and perpetrators of the Rwandan Genocide. The new Rwandan government, headed by the Rwandan Patriotic Front (RPF), ${ }^{6}$ adopted a stance of maximal prosecution: every single participant in the genocide, from the central planners down to coerced peasant farmers or opportunistic looters, would be prosecuted and punished for their crimes. Article 2 of the 1996 "genocide code" delineates four categories of responsibility in the genocide: (1) "planners, organizers, instigators, supervisors and leaders of the crime of genocide or of a crime against humanity," persons of positions of authority in the government or political parties, "notorious murderers," and "persons who committed acts of sexual torture"; (2) perpetrators or "conspirators of accomplices" of intentional homicide or physical assault causing death; (3) persons guilty of "serious assaults against the person"; and (4) persons who committed crimes against property. ${ }^{7}$ Subsequent amendments to this legislation, including the laws establishing the Gacaca courts and amending their structure and statutes, have maintained this hierarchy of responsibility, with punishments varying in severity by category. ${ }^{8}$ Justice mechanisms at the international, national, and local levels have attempted to prosecute and punish those responsible. Yet many genocide survivors and victims still feel that justice is elusive.

On the international plane, the UN Security Council created the International Criminal Tribunal for Rwanda (ICTR) in November 1994 to prosecute persons responsible for genocide and other serious violations of international humanitarian law committed between 1 January 1994 and 31 December 1994, in Rwanda and in neighboring states. ${ }^{9}$ The hope was that the ICTR would allow prosecution of the genocide planners who had fled the country. The first ICTR trial, that of Jean-Paul Akayesu, former bourgmestre (mayor) of Taba commune, started in January 1997 and ended in October 1998. Akayesu was found guilty of nine counts of genocide and crimes against humanity, including the use of rape as a weapon of genocide, and was sentenced to life in prison. ${ }^{10}$ Most Rwandan citizens felt completely marginalized by 
the ICTR in the early years of its existence, but public information campaigns in Rwanda sponsored by the ICTR, the Hirondelle Foundation, and Internews made most Rwandans aware of the tribunal's activities by the late 1990s and early 2000s. Many Rwandans have followed the progress of the trials via radio news reports, newspapers, or the Internet; in particular, they were interested by high-profile cases such as the "media trial," in which the owners of extremist anti-Tutsi propaganda newspapers and radio stations were prosecuted, and the "military trial," in which several highly placed officers, including Colonel Théoneste Bagasora, were prosecuted. Yet many Rwandans view the institution as unjust, since people prosecuted before the ICTR face less severe penalties than those tried inside Rwanda and enjoy "luxurious" prison conditions. ${ }^{11}$ In addition, both the vast resources invested in the ICTR and its slow progress have encouraged additional criticism, and the Rwandan government has, when politically expedient, encouraged negative sentiment toward the ICTR. ${ }^{12}$

Under the principle of universal jurisdiction, several foreign governments have attempted to prosecute Rwandans for genocide crimes. The first such case was the trial of a National University of Rwanda professor and four nuns in Belgium in 2001; all were found guilty and sentenced to imprisonment. More recently, Canada has prosecuted Desiré Munyaneza under Canada's Crimes Against Humanity and War Crimes Act, passed in 2000. Munyaneza, the son of a wealthy businessman, fled to Canada in 1996 or 1997 . He was denied refugee status after a series of numerous hearings and was arrested in 2005 and charged with two counts of genocide, two counts of crimes against humanity, and three counts of war crimes. ${ }^{13}$ His trial began in March 2007; it is still underway, and unlikely to finish before the end of $2008 .^{14}$ Prosecutions of genocide suspects continue before numerous European courts, and the Rwandan government has begun to investigate suspects who fled and are living abroad so that it can request their extradition. ${ }^{15}$

At the national level, the RPF-led transitional government, along with international consultants developed Rwanda's "genocide code," promulgated in August 1996, to govern the prosecution of genocide crimes by the state. The first trials began in December 1996 and have continued, slowly, up to the present. In the late $1990 \mathrm{~s}$, prison and local jail populations in Rwanda soared to more than 130,000, almost all imprisoned on charges of genocide. The Rwandan justice system, itself destroyed in the genocide, which also decimated its personnel, was overwhelmed, and trials moved forward slowly. As of March 2001, the national courts had tried 5,310 people, according to Human Rights Watch. ${ }^{16}$ Even if Rwanda had had the best justice system in the world, it would have been overwhelmed by the problem of trying genocide suspects. Under pressure from the international community to solve the problem, the Rwandan government turned to gacaca, a traditional conflict-resolution mechanism.

In its "traditional" form, gacaca brought together inyangamugayo ("people of integrity," who were usually respected elders), the parties to the dispute, and residents of the hill to establish the facts of the conflict and find a solution. Gacaca takes it name from a patch of grass found in the inner courtyard (igikari) of a traditional homestead. This inner courtyard was the most private place in the family home and usually only family members were permitted to enter it; the inner courtyard was the domain of the wife of the household, and her husband had to ask permission before entering. Thus, gacaca in its traditional form was a private rather than a public affair. The deliberations in gacaca were considered confidential, and even the "judgment" or decisions of gacaca were reported publicly only if such reporting was a specific decision of the gacaca process. 
Under Belgian colonial rule, tribal courts overseen by local chiefs were established to handle disputes among the indigenous population, while "modern" Belgian-style courts were established to handle legal disputes involving the foreign (mostly white) population. The laws of the colonial state, relegated to the Belgian-style colonial courts, applied only to Europeans and to certain other categories of foreigners, while "customary law" (relegated to the "tribal" courts) applied to Rwandans and other Africans. Gacaca continued to operate during this period, but its decisions were enforced by local chiefs only if these chiefs recognized the legitimacy of a specific gacaca and its decisions. In the postcolonial period, the Belgian-style "modern" courts replaced the "tribal" courts; in some communities, however, local administrators began holding gacaca sessions to resolve disputes among rural peasants without involving the modern legal system. ${ }^{17}$ While gacaca was used by local officials under the Habyarimana regime, the practice was never codified by Rwandan law, so the exact format and function of gacaca varied widely from community to community. In addition, families continued to resolve intra-familial conflicts through gacaca when necessary.

Exactly when gacaca was proposed as a possible remedy for Rwanda's postgenocide judicial woes is unclear. In 1996, the UN Human Rights Mission to Rwanda commissioned a study of gacaca by several Rwandan professors from the National University of Butare. ${ }^{18}$ The report documents several forms of gacaca throughout the country, even finding a few communities where it had been applied to solve local disputes in the absence of a functioning judiciary in 1995 and early 1996, but the authors concluded that gacaca was not appropriate as a judicial remedy for the genocide. Political scientist Timothy Longman dates the gacaca solution to a conversation between Michele Wagner, a historian of the region and then a researcher for Human Rights Watch, and some professors from the National University on the terrace of the Hotel Ibis in Butare in $1995 .{ }^{19}$ Regardless of the origins of the idea or the initial negative results of studies, gacaca emerged as the only possible solution in the eyes of the Rwandan government and many members of the international aid community, despite widespread opposition from the international human-rights community. International human-rights organizations have criticized the Gacaca courts because their procedures violate the fundamental rights of the accused by prohibiting them from seeking legal counsel and not granting them full rights to crossexamine prosecution witnesses or to call witnesses for their defense. ${ }^{20}$ As Peter Uvin and Charles Mironko state, "perhaps the strongest element in favor of gacaca is the lack of an alternative." 21

In January 2001, the original legislation creating the Gacaca courts was passed by the National Assembly. The reinvented Gacaca courts changed many of the fundamental aspects of the traditional gacaca. The first and most important difference is that the Gacaca courts have made the proceedings a public, rather than a private, affair, with the entire community participating. Second, the foundation of Gacaca court proceedings is the testimony of prisoners who have confessed to their crimes. In traditional gacaca, testimony usually began with the aggrieved stating their case, followed by impartial witnesses providing testimony. The accused completed the proceedings by giving their testimony while participants cross-examined them based on the accounts provided by witnesses. Third, the foundation of traditional gacaca was not punitive justice but, rather, restorative justice. Although the recommendations (or "judgments") of a traditional gacaca might have included some punishment (e.g., the gift of a cow, goat, or other livestock), these punishments were focused on 
Table 1. Prison Population in Rwanda

\begin{tabular}{ll}
\hline Year & \# Prisoners \\
\hline 1995 & $57,000^{\mathrm{a}}$ \\
1996 & $83,000^{\mathrm{b}}$ \\
1997 & $120,000^{\mathrm{c}}$ \\
1998 & $126,000^{\mathrm{d}}$ \\
1999 & $150,000^{\mathrm{e}}$ \\
2000 & $125,000^{\mathrm{f}}$ \\
2001 & $100,000^{\mathrm{g}}$ \\
$2002-2005$ & data unavailable \\
2006 & $60,000^{\mathrm{h}}$ \\
2007 & $97,000^{\mathrm{i}}$ \\
\hline
\end{tabular}

${ }^{\mathrm{a}}$ Human Rights Watch [HRW], World Report 1998 (New York: HRW, 1998).

${ }^{\mathrm{b}}$ HRW, World Report 1999 (New York: HRW, 1999).

${ }^{\mathrm{c}}$ HRW, World Report 2000 (New York: HRW, 2000).

${ }^{\mathrm{d}}$ HRW, World Report 2001 (New York: HRW, 2001).

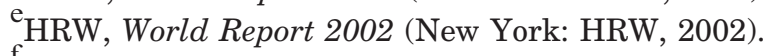

${ }^{\mathrm{f}}$ Hirondelle News Agency, "Rwanda Wants to Relieve Congestion in Prisons," Rwanda Development Gateway, December 6 2007, http://www.rwandagateway.org/article.php3?id_ article $=7543$ (accessed 16 May 2008).

g Ibid.

h Ibid.

${ }^{\mathrm{i}}$ HRW, "Rwanda-Human Rights Overview," in World Report 2008 (New York: Human Rights Watch, 2008).

reestablishing social equilibrium between the disputing parties and lineages. When a gacaca judgment included the gift of livestock, such a gift was to be made with all the attendant ritual ceremony normally accorded to such a gift and with all the subsequent counter-gifts required for a gift of livestock. The Gacaca courts have attempted to include aspects of restorative justice through the inclusion of "work of general interest" (a sort of community service) and the payment of reparations to the victims' families or to the Genocide Survivors' Assistance Fund as part of perpetrators' sentences. Yet, in the communities where my research was conducted, the perception of the Gacaca courts is that they are entirely focused on punitive justice. The Gacaca courts can impose sentences ranging from "civil reparation of damages caused to other people's property" to the death penalty or life imprisonment. ${ }^{22}$

Despite this reinvention of a private conflict-resolution mechanism as a public, punitive justice mechanism, the Rwandan population, including survivors, the accused, and families of the accused, maintained hope that the truth might emerge, justice might be served, and the falsely accused might be released. ${ }^{23}$ Elections for inyangamugayo were held in late 2001, and a pilot phase of Gacaca began in 2002.

As a result of the RPF's policy of maximal prosecution, Rwanda's prisons gradually filled following the RPF victory in July 1994. With the return en masse of more than a million refugees in late 1996 and early 1997, the prison population ballooned, and by 2001 more than 130,000 people were in prison, accused of genocide. ${ }^{24}$ This massive prison population put a strain on state resources; the Rwandan government was unable to provide adequate food, water, or living quarters for prisoners, most of whom 
were imprisoned in local, makeshift jails, usually structures originally intended for other purposes. The family members of prisoners were required to bring food and drinking water at least once a week to sustain their imprisoned relatives. Gacaca was the Rwandan government's proposed solution to the problem of mass incarceration.

In public statements, the Rwandan government expressed its hope that Gacaca would help with the problem of mass incarceration of people accused of genocide. The prisons would be emptied and the drain on state and community resources would be stopped. In early 2003 (a few months before parliamentary and presidential elections), President Paul Kagame provisionally released several thousand prisoners who were elderly or sick or who had been minors in 1994. Again in July 2005, August 2006, and February 2007 authorities provisionally released tens of thousands of detainees who were elderly or sick, had been minors in 1994; this release also included those or had confessed to participating in the 1994 genocide and had already served the maximum sentence for their category of crime. ${ }^{25}$ Released prisoners attended a sixweek re-education camp (ingando) before returning to their home communities. Despite these steps to reduce the prison population, Gacaca has resulted in an exponential increase in the number of accused. Furthermore, the number of detainees in Rwandan prisons and jails has been on the rise, from 60,000 at the beginning of 2006 to around 90,000 in May 2007. ${ }^{26}$

Following the pilot phase from 2001 through 2002, the Gacaca statute and the entire Rwandan judiciary were reorganized based on the results of this phase. Organic Law No. 16/2004 was promulgated on 19 June 2004, and the Gacaca courts began operating nationwide in January 2005; the secretary of state of the Ministry of Justice stated that approximately 761,000 suspects had been identified in the investigation phase of Gacaca. ${ }^{27}$ In December 2007, Domitille Mukantaganzwa, executive secretary of the National Service of Gacaca Courts, announced that 712,723 of a total of more than 1.12 million cases had been completed. ${ }^{28}$ Presumably, many of these cases involve more than one person.

\section{Putting Justice before Truth}

A persisting difficulty for Rwandans in general, and for genocide survivors in particular, is determining when, where, and how their loved ones died. ${ }^{29}$ Having stopped the genocide, the RPF has used its symbolic capital as the "savior" of Rwanda to legitimate its dictatorial rule. Thus, knowing the truth about the genocide is a political need. Yet, for genocide survivors, this need to know the truth is not merely political or psychological; it is also spiritual and metaphysical. According to traditional Rwandan religious beliefs, the dead inhabit our world as ancestor spirits, who cause trouble for the living if they are displeased. Keeping the spirits happy requires a sacred burial and regular offerings of food and drink. ${ }^{30}$ While the majority of Rwandans adopted Roman Catholicism at some point during the twentieth century, traditional beliefs still influence the feelings of those who have converted. Furthermore, Catholic beliefs about purgatory and heaven further emphasize the emotional, psychological, and spiritual need to honor the dead through proper burials.

Gacaca courts were portrayed as a way to uncover the truth about the genocide. In some communities, Gacaca has served as a mechanism for establishing the truth. Anuradha Chakravarty has documented the complex ways in which the logic of genocide has been deconstructed in some sector-level Gacaca hearings. ${ }^{31}$ Some survivors have recovered the remains of their loved ones thanks to testimony given before the Gacaca courts; others have learned more precisely how, when, or where their loved 
ones were killed. For many others, however, the truth has remained elusive. The accused were offered reductions in sentences for confessing to their crimes, and thousands have confessed, but many Gacaca courts are rejecting these confessions as incomplete or untrue. ${ }^{32}$ Given the benefits of confession, it is understandable that some people might confess to less severe crimes than the ones they committed, while others may have confessed to crimes they did not commit in order to be liberated. ${ }^{33}$ In some communities, clandestine groups known as ceceka ("keep quiet") have organized a code of silence before the Gacaca courts. ${ }^{34}$ Thus, many genocide survivors fear that the truth will not be restored to them through the Gacaca process.

For the accused, their families, and other Hutu, the fear is that the Gacaca courts will be used for other ends than justice for the genocide. In some communities, genocide survivors and others have organized themselves to fabricate testimony and evidence against certain people. ${ }^{35}$ In some cases, they appear to be motivated by the desire for reprisals or revenge-they feel as if they know that certain people were involved, and they want to make sure that these people are found guilty. In other cases, testimony is fabricated for other purposes, such as to settle long-term personal conflicts, family feuds, or disputes over land or other property.

Soldiers recruited by the RPF during the civil war are sometimes behind these campaigns to denounce people in Gacaca. Between 1990 and 1994, the RPF engaged in large-scale, clandestine recruitment of Rwandans. This situation generated mistrust among the population, and extremist Hutu propaganda played on these fears with such statements as "the enemy could be hiding anywhere." In his study of perpetrators, Scott Straus cites these war-related fears as the second most frequently reported motivation for perpetrators. ${ }^{36}$ As a result of these fears and propaganda, the families of RPF soldiers were often the first ones targeted in the genocide. Today, RPF soldiers whose families were decimated are (understandably) angry, and many seek revenge through the Gacaca courts against anyone they know who is Hutu. ${ }^{37}$

Another problem is that the Gacaca process is perceived as one-sided, as victors' justice. ${ }^{38}$ The Gacaca law states that the courts have jurisdiction only over crimes related to the genocide; thus, killings and other atrocities perpetrated by RPF soldiers, whether during the pre-1994 civil war, during the genocide and its aftermath in Rwanda, or in the Democratic Republic of Congo, are off the table. Although the documentation of RPF abuses committed in 1994 is sparse, several sources report indiscriminate killings of civilians; extrajudicial executions of suspected or accused génocidaires; and expropriation of houses, livestock, and other property. ${ }^{39}$ As the RPF took control of new areas, it set about separating the civilians from the Interahamwe zariye abantu ("genuine Interahamwe," meaning those who killed a lot). It relocated civilians to camps and then executed the Interahamwe. General Paul Kagame explained the policy on Radio Rwanda: "harmful elements were hidden in the bushes and banana plantations. Therefore a cleaning was necessary, especially to separate the innocent people with the killers." 40 The RPF called these campaigns of indiscriminate killings gutwika ahantu ("to set a place on fire"). When the refugees returned en masse from Zaire and Tanzania in late 1996 and early 1997, the RPF sorted the Interahamwe zariye abantu from the other civilians. The notorious Interahamwe (the "big killers") were often executed on the spot.

As a result of the campaigns to root out "real Interahamwe," many Rwandan citizens feel that Interahamwe nyanterahamwe ntizikiba mu Rwanda ("the true Interahamwe are either dead or in exile"). Thus, the people accused in Gacaca courts 
are not "real Interahamwe"; at best, they are small-time participants who were coerced into action, and they may be completely innocent.

Many other civilians lost their lives at the hands of the RPF; both Hutu and Tutsi had something to fear from the RPF, as the soldiers frequently made no attempt to distinguish between them, presuming that anyone who had survived must have killed or been an accomplice in the genocide. ${ }^{41}$ In cases of "mixed" marriages between Tutsi women and Hutu men, RPF soldiers would sometimes kill everyone to punish the Tutsi for "collaborating" with (i.e., literally "sleeping with") the enemy. ${ }^{42}$ Those who have been victims of RPF abuses or witnessed these abuses, whether Hutu or Tutsi, fear that the whole truth will not be known.

\section{The Injustices of Local Justice}

An important issue that emerged in all focus-group interviews conducted in 2007, and was mentioned in many other conversations in 2007, is the problem of integrating released prisoners and génocidaires, meaning those who have confessed to and been sentenced for crimes of genocide, into the local community. Beginning in 2003, as mentioned above, large numbers of prisoners were provisionally released, beginning with the old, the infirm, and those who were children at the time of the genocide, pending trial in Gacaca. ${ }^{43}$ Prisoner releases have continued, and, since Gacaca courts began operating nationwide in January 2005, many of the more recently released prisoners have been either convicted and sentenced or found innocent.

In preparation for Gacaca, the government waged a public-awareness campaign to educate both prisoners and the general population about the need to accept released prisoners, whether innocent or guilty, back into the community. Such "sensitization campaigns," as they are called in Rwanda, have a long history and are commonly employed both by the government and by international NGOs to "educate the population" or to "change local beliefs." In the focus groups, I frequently heard various versions of the "official" response to prisoner releases, that is, the response citizens were instructed that they should have:

Once they [released prisoners] arrive on the hill, they get along very well. They try to ask for forgiveness from people whose family members they killed. ${ }^{44}$

The prisoners had received training sessions in ingando [re-education camp] before coming onto the hill. You can see, once he [a released prisoner] arrives on the hill, he has changed a lot. First of all, he prays a lot. You can see that he is truly Christian. Second, he approaches people to talk and to ask forgiveness from people against whom he committed genocide, whose family member he killed. Third, he goes to help others. ${ }^{45}$

I went to visit a freed man at his home who lived really close to my house and he came to visit me at home too. We have exchanged ideas and I've seen that this is someone who has totally changed. We should have the courage to approach these people. This man of whom I'm telling you, he killed my family, he asked forgiveness and I forgave him. I find that it's good if someone truly accepts these actions and asks forgiveness, at this time he is relieved and you, too, you feel something like peace in your heart. ${ }^{46}$

In focus groups conducted in mixed company-that is, those whose participants included both Tutsi and Hutu widows of the genocide and Hutu wives of current or former prisoners (in Southern province) or both Tutsi returnees and Hutu women (in Northern province), the vast majority of respondents were very careful to stick to this official, idyllic version of prisoner reintegration into local communities. In many cases, in more private contexts, the very same respondents would recount an entirely 
different version of what was happening. Some women even waited for others to leave following the focus-group discussion so that they could add to or change what they had told me.

In more homogenous groups of women, I heard less rosy depictions of prisoner reintegration. Widows of the genocide (whether Tutsi or Hutu) explained the difficulties of accepting known génocidaires back into the local community:

In general, the prisoners integrate themselves without any trouble. But, there is one who came who did not change. He, he stays at home, he talks to no one. Since he did very bad things in the genocide, killed a lot, we leave him alone like that. We've put him in quarantine. ${ }^{47}$

We can't look into men's hearts, certainly there are those who are happy and others who are not happy. In general, we pretend to get along. ${ }^{48}$

The sentiments expressed here are not surprising. It is not hard to imagine how difficult it must be for genocide survivors to live as neighbors with people responsible for hunting them, looting and burning their homes, or killing their family members.

What I find striking about the two statements cited above is the subtle differences in the attitudes behind them. The first was made by one of the key leaders of the church-based women's organization of which all the focus group were part. She was herself an inyangamugayo in the Gacaca court in her sector, and she had courageously served as an unbiased leader in the Gacaca process by helping to ensure that the innocent were released and by punishing false testimony. Yet she admits freely that certain génocidaires do not have the right to rejoin the community, since basabye imbabazi ("they have asked for mercy") before the courts by pleading guilty and admitting the acts they committed but have not batyicuza ("shown remorse"). In our conversations and interviews many Rwandans, whether Tutsi genocide survivors or Hutu who did not participate in the genocide, drew attention to this qualitative distinction in the types of confessions made by génocidaires. To confess (gusaba imbabazi) before the courts, receive a reduction in sentence, and be released from prison is not the same as accepting moral responsibility and showing remorse (kwicuza). Both of these Kinyarwanda phrases mean "to ask for pardon," but gusaba imbabazi is used primarily in the legal arena, whereas kwicuza is used by Roman Catholics to refer to asking pardon during the rite of confession.

The second statement was made by a widow of the genocide, speaking in a focus group made up of two small women's groupings from a very rural area of Southern province, the first comprising widows of the genocide and the second, Hutu wives of prisoners. During the interview the Hutu women hardly spoke and gave very constrained responses, while the leader of the widows' group did most of the talking. Her statement above, especially given that she made it in front of her Hutu neighbors, was intended to underscore the continuing distrust and suspicion among Tutsi survivors of the genocide.

In response to a follow-up question, the same widow returned to the same theme by evoking the lasting trauma (guhahamuka) of genocide:

We cannot forget the wounds that we have in our hearts, but the Gacaca [process] has warned us to be patient and courageous. If you begin to feel trauma in the Gacaca [trial], you cannot get anywhere. I can't forget that I am left alone. When I don't have water in the house and night is falling, I think that I should have someone to go draw water. When there is no wood for the fire, that reminds me that there should be someone to go and collect wood. When I want this or that, I should have someone 
to help me. With everything that I do, I am reminded that I am alone. That's how it is, we go to Gacaca, we try to be patient, but forget all that, it will never happen. ${ }^{49}$

The fundamental message here is that there can be no justice for genocide survivors. Whether through Gacaca or any other judicial process, genocide survivors will never have justice, because the gaping holes in their lives cannot be filled. No one can bring their dead family members back to life.

While I have encountered these and similar sentiments among survivors over the years, they are not common to all survivors. Survivors have many different points of view on the "events of 1994," on justice, and on the appropriate way to remember the genocide and their lost loved ones. All have been unanimous that dead family members can never be replaced or compensated for, but many view justice through the courts (whether national or international) or through Gacaca as an important duty-a way to recapture the dignity of those who died in ignominious ways. One widow from Southern province has collaborated extensively over the years with investigators from the ICTR and from foreign governments. She has testified before foreign courts on several occasions, at great emotional cost to herself. Yet she has undertaken all these activities quietly and discreetly, to avoid attracting attention and potential revenge seeking. Also, she has not participated or volunteered to participate in investigations conducted by Rwandan authorities. When I asked her why, she said that she could not work with these authorities because they "were not serious."

A second issue raised in several conversations and focus group interviews is the problem of new accusations against people who have been living in the community "peacefully" for the past twelve years. While I was visiting a family in Western province, the conversation fell on the topic of Gacaca spontaneously. Several neighbors and members of the patrilineage had gathered in the living room to welcome me, in the customary fashion, with beer and conversation. The woman with whom I had come lived in Kigali and rarely came to see her family, so she was catching up on local news. Her sister-in-law asked, "Did you know that [name deleted] has become insane?" The others quickly began explaining:

It's not surprising because we just heard that he, too, killed during the genocide. It's someone who was released from prison thanks to the President of the Republic who told us that. He said that [name deleted] had participated in the genocide. People asked the freed man why he didn't say anything sooner.

[Interjection:] He is ready to denounce him and give all the information if the Gacaca court calls him. ${ }^{50}$

While this gathering of family and friends was shocked to find out that this particular neighbor had participated in the genocide, they did not feel that the accusations were anything other than the truth. For me, it was a relief to see them discussing Gacaca and its complexities without fear and suspicion. The group included (Tutsi) genocide survivors, (Hutu) former prisoners and family members of former prisoners, (Hutu and Tutsi) members of the RPF who had joined during the civil war between 1990 and 1994, and (Hutu) supporters of the late President Habyarimana and his party, the MRND (National Republican Movement for Democracy and Development). Yet the ties among them were strong enough to allow for what appeared to be unfettered discussion. The conversation then turned to the dark side of new accusations of genocide:

Woman: I see that [name deleted, her cousin] has been imprisoned again.

The Others: This gentleman has killed quite a lot of people in the genocide. He admitted it himself. Only, after he was released from prison, that's when he began to lie, denouncing innocent people by saying they had 
participated in the genocide. After he had denounced a large number of these people, the population realized that he was lying. He, himself, said, "No one visited me or ever brought me something to eat when I was in prison, I will take my revenge." After that, people realized that these others were innocent. The population is waiting patiently to see if the inyangamugayo are going to do something and if these people will be released from prison. ${ }^{51}$

The foundation of the Gacaca process has been the testimony of prisoners who plead guilty in exchange for a reduction in sentence and their testimony at the Gacaca hearings. Prisoners have many motivations to lie. As in the case cited above, some may lie to seek revenge. The theme of revenge is a very strong one in Gacaca, and its current goes in many directions, as I discuss further below. Other prisoners may lie because they did not make a full confession and want to cover up some of the atrocities they committed in the hope of avoiding longer sentences or more severe punishments.

One effect of new accusations is that they disrupt the social fabric that has been tenuously rewoven in certain communities. In a focus group in Southern province, a Tutsi widow explained,

In Gacaca not everything is going well. You see a husband and a wife who have lived on the hill [and not left] for thirteen years, we believe they are innocent and all of the sudden you hear them denounced in Gacaca, they did this or that. The family [the husband and wife] is shocked, discouraged and gets angry saying that this [the accusation] is motivated by hate. There are interminable conflicts. ${ }^{52}$

Here the speaker leaves open the question of whether the accusations are true or false; instead, she highlights the fact that, regardless, the family of the accused perceives the accusations as injustice, as the seeking of revenge. The belief that accusations are motivated by revenge is not merely paranoia; such beliefs are based on known cases of revenge within the community, whether in the immediate aftermath of the genocide, following the mass return of Hutu refugees from exile in 1996 and 1997, or in Gacaca itself. The problem here is that the legitimacy of Gacaca has been so undermined in some communities that residents dismiss all testimony as lies or half-truths.

In conversations and interviews I conducted in 2007, numerous examples of revenge seeking in Gacaca emerged. These cases appear to fall into three main categories: revenge against particular individuals, revenge against particular individuals as representatives of a corporate group, and revenge against a corporate group.

In instances where people sought revenge against particular individuals, the events in question had not necessarily occurred during the 1994 genocide. Sometimes they appeared to be taking revenge for events in the distant past (e.g., during previous periods of anti-Tutsi sentiment and violence, such as occurred in 1959, 1962-1963, and 1973). Most of these stories are difficult to describe in ethnographic detail because they risk endangering the tellers who are the victims of this revenge seeking. One Tutsi genocide survivor, Marie ${ }^{53}$ who had been married to a Hutu, Janvier, explained to me how another Tutsi genocide survivor, Jeanne, constantly terrorized her during Gacaca hearings. Jeanne would frequently appear before the court and demand that Marie testify about what had happened during the genocide. Marie insisted that she did not witness anything, having spent several months in hiding with her children, moving from house to house among her in-laws, who lived near one another on the hill. Jeanne insisted that Marie was lying, that she knew where victims' bodies were buried. Jeanne repeatedly threatened, "Don't you know what the punishment for lying before 
the Gacaca court is!?!" As Marie told me her story, her body trembled, her voice quavered, and tears fell silently from her eyes.

Jeanne and her husband, Patrice (also a Tutsi who had survived the genocide), had long held a grudge against Marie and her husband. Patrice had been the victim of Tutsi purges from higher education in 1973, and he blamed anti-Tutsi racism for the premature end of his education. He eventually focused this anger on Marie's husband, Janvier. In the early 1990s, Janvier had been promoted to a leadership position in the regional government; Jeanne and Patrice believed that Patrice had been unfairly passed over for the same promotion because of his ethnicity. In the months following the genocide in 1994, Janvier continued to hold this position in the regional government and worked closely with the RPA officers stationed in the area. ${ }^{54}$ One day, as he was walking on the main road into town, a truck transporting prisoners stopped; without any explanation, Janvier was arrested by the soldiers accompanying the prisoners and subsequently imprisoned. It took Marie several weeks to find out what had happened to him. She eventually found him in a provincial prison. Only several months later did she find out that he stood accused of genocide, although he did not even have a judicial file.

With the loss of her husband's salary, Marie sought assistance for her children from the Genocide Survivors' Assistance Fund (FARG), but Jeanne and Patrice, who headed the local genocide survivors' organization, blocked Marie's efforts by refusing to sign the necessary paperwork. Jeanne said to her, "The FARG does not help killers' children." Marie's husband spent seven years in prison on charges of genocide, although there was no evidence against him in his dossier. Marie and her husband believed that Jeanne and Patrice were behind his arrest and imprisonment, but they had no proof of it.

When Marie's husband was finally released in 2001, many (Tutsi) genocide survivors in the community were pleased to see him and welcomed him back home. Patrice and Jeanne, on the other hand, harassed the family and insisted that Janvier would be rearrested. On one occasion, Patrice tried to organize a mob to attack Janvier. ${ }^{55}$ Under great psychological strain, Janvier went to the capital city, Kigali, hoping to escape the harassment, but it continued. The family he was staying with there began to receive anonymous, threatening phone calls; Janvier became paranoid, believing that he was constantly being watched and followed. One evening, he was hit by a dump truck while crossing the street. He died from his injuries. While Marie believed that Jeanne and Patrice had something to do with the incident, she had no proof, and police investigators labeled Janvier's death an accident. Trying to support her children alone, Marie hoped that Jeanne and Patrice would leave her in peace, but every time she attended Gacaca ${ }^{56}$ she faced Jeanne's accusations.

The Rwandan government's genocide commemorations and national mourning practices generate a polarizing discourse that defines all Tutsi as genocide victims and all Hutu as genocide perpetrators. ${ }^{57}$ Under this logic, certain Tutsi genocide survivors have sought revenge against individual Hutu as a scapegoat for Hutu as a corporate group.

Among women's groups in Southern province, ${ }^{58}$ several of the Hutu members had faced accusations before the Gacaca courts. In most cases, the association members, including genocide survivors, had conducted investigations to assess the validity of the accusations. They then helped the accused group member launch a defense before the court by locating witnesses and ensuring that the witnesses appeared to testify. 
In a dramatic turn of events, however, one member, a (Tutsi) widow of the genocide, turned against another member, a (Hutu) widow whose husband had been killed by RPF soldiers in 1995:

Author: Has the Gacaca process had any negative effects on you or your association? Woman: We mustn't lie to you; the Gacaca process has had its negative effects. For example, our group leader was imprisoned [whispering]. There was an American researcher who came to interview women in the association on the topic of Gacaca. In the meeting, D. [name deleted] said that there is injustice in Gacaca because all the genocide survivors want to make certain that all the Hutu are imprisoned. After a woman in the association went to see the inyangamugayo in [sector name deleted] to denounce D., she also wrote a letter saying that D. had engaged in divisionism. D. was arrested and imprisoned for four months. Because of the accusations of divisionism, the case went all the way to the Office of the National Prosecutor in the normal courts. When D. went before the Gacaca court, our group members went to testify on her behalf and said that she hadn't participated in the genocide and that she hadn't divided people and that she likes peace in the community. Afterwards, the Prosecutor also made inquiries. In the end, D. was released.

Author: How has all this affected the association?

Woman: We had some trouble getting along during that period, but T. asked forgiveness $[k w i c u z a]$ from all the association leaders and also from D. Now, there aren't any more problems. D. forgave T., who is still remorseful. We try to show T. that there is no problem. ${ }^{59}$

Despite these statements, it was clear in my interactions with the members of the association that the story was far from over. D., a vibrant, smiling group leader when I first met her in 2000, had become a shadow of her former self. She walked with her head bent, eyes on the ground, and didn't say a word. The toll taken by her time in prison was evident in her gaunt face, worried eyes, and white hair. While she was imprisoned her children had been forced to drop out of school to take care of the family farm and to bring her food and water. D. did not say a word in any of the meetings and left the room anytime the subject of her imprisonment and T.'s actions came up. She avoided having any conversations with me.

In a meeting the following week with all the association leaders, I asked some questions about Gacaca. After many women said that Gacaca was working well, a Hutu widow of the genocide stood up and said that there was "justice for some in Gacaca, but not justice for all." Immediately, T. stood up and accused her of divisionism in front of everyone. The meeting became very tense, and everyone was upset. Several women spoke in rapid succession, interrupting one another. In the end, a Tutsi widow of the genocide admonished T. for "restarting her nonsense" and told her that she would be thrown out of the association if she continued.

According to some women in the group, T. was lashing out against D. because T. had lost her husband and all but one of her children and, in addition, had contracted HIV when she was raped in 1994. As her health declined, she became more and more bitter and began to lash out against Hutu association members, even those who were widows of the genocide.

The statement that had landed D. in prison, that some genocide survivors will not stop until all Hutu are in prison, was a sentiment I heard in all three provinces during my visit in May and June 2007. These statements were made only in intimate groups where everyone trusted those who were listening. As D.'s case illustrates, making these statements is very risky. 
During a focus group with a women's association in Northern province, the members all said that Gacaca was working well, that innocent prisoners were being released, and that the perpetrators were being found guilty and sentenced. Following the meeting, a few members lingered to chat. After one member, a (Tutsi) woman who had grown up in Burundi and returned to Rwanda after the genocide, left, the subject turned back to Gacaca. The remaining women (all of whom were Hutu) began speaking in low voices, so that our conversation could not be overheard. They said that Gacaca was not functioning well at all, that it was "profoundly dividing" the population along ethnic lines:

Member \#1: Before, pastoralists and farmers ${ }^{60}$ in this region could talk to each other. In 1998, 1999, and 2000, when conflicts arose between them, for instance, when someone's cattle grazed in someone's fields, we could bring them together, negotiate, and settle the problem. Since Gacaca has started, both live in fear. They don't talk to each other. In front of each other, we don't say what we really think. That's why we couldn't say what was really happening [before the Tutsi returnee left].

Member \#2: What we see now is that the inyangamugayo won't stop until all the educated Hutu are in prison with long sentences.

Author: $\quad$ Are all the inyangamugayo Tutsi?

Member \#1: $\quad$ Not only Tutsi, they are fifty-niners. ${ }^{61}$

Member \#3: I was an inyangamugayo. When I saw people giving false testimony and getting innocent people imprisoned, I denounced it. The other inyangamugayo told me to keep quiet, but I went to Kigali and told them [the Ministry of Justice] that the inyangamugayo here were not implementing the law correctly. They sent investigators here. Next thing you know, someone is denouncing me in Gacaca. I got the message. I resigned, and I kept my mouth shut. No one sang my name in Gacaca anymore. ${ }^{62}$

Gacaca has been much touted as a reconciliation mechanism, and, indeed, its traditional purpose was as a conflict-resolution mechanism. However, as it is currently being implemented in many communities, Gacaca is deepening cleavages within those communities and sowing mistrust on all sides. Ibuka, a national association of genocide survivors, notes the deepening of ethnic divisions in a recent, mostly negative, report on Gacaca. ${ }^{63}$

Beyond these injustices and the use of Gacaca for revenge, the process is also being used by some people to seek other gains. Stories of people denouncing others before Gacaca in order to "take their land" are rampant in Rwanda; I heard them in all the communities I visited. The story is so ubiquitous that it strikes me more as a metaphorical statement about Gacaca and its injustices than as an accurate account of the usurping of land. Yet in rural Northern province, I encountered very direct statements about land usurpation tied to Gacaca in a focus group with a women's organization in the former Kinigi commune. Since the RPF victory in 1994, a large number of Tutsi pastoralists have moved into Kinigi with their cattle, which they grazed on the shoulders of the volcanoes. Between 1999 and 2001, Kinigi was seriously affected by an insurgency that entered Rwanda from the Democratic Republic of Congo via Birunga National Park. As part of its counter-insurgency operations, the Rwandan government forced the population of Kinigi to relocate into internally displaced persons (IDP) camps; many were forced to destroy their houses, some of which were modern brick houses with glass windows and metal doors, before moving into the IDP camp. When I first met this women's group, they were living in deplorable conditions in small shelters made of UNHCR tarps, crowded together at the foot of one of the 
volcanoes. Since the end of the insurgency, they had not been allowed to return to their homes; instead, the government had forced them to settle in an umudugudu ("agglomeration") under its villagization policy. ${ }^{64}$

In 2007, I tried to meet with the group again, but when my research assistant and I arrived late for the meeting, the women had gone home. My research assistant returned a few weeks later to interview the women. When she asked them about how released prisoners were being integrated into the community, this was the response:

Up until now, we have not yet seen any prisoner releases. On the contrary, many people are being imprisoned. What we see here is a problem of land holdings. Kinigi is inhabited by a lot of Tutsi and the fifty-niners want all the land. So, to get the land, the Tutsi and the fifty-niners who have money, they find Hutu and give them this money so that they can go and give false testimony. Those that they accuse directly are quickly put in prison and the others take their land, saying that their grandparents lived in these places for a long time. The inyangamugayo just discovered this and they said in a meeting that there are people with big bellies [bafite inda nini, meaning that they are very poor, greedy, or wicked] and they give false testimony to get people arrested for nothing just because of money. They warned us not to start that again. ${ }^{65}$

In other regions I encountered similar stories of people using Gacaca to seek other gains, whether land or jobs, or to "settle" family disputes by getting someone else imprisoned. It is not surprising that some citizens are using Gacaca as a lever to get what they want; this phenomenon has a long tradition in the regular courts, as well as in other bureaucratic venues. For instance, in his 1968 monograph Pierre Gravel shows that cases brought before tribal courts were "trials of powers" rather than "trials of rights," meaning that a court case was decided not on the basis of whose rights had been violated but, rather, on the basis of whose power within the community was greater. ${ }^{66}$ In my own experience of using the traditional form of gacaca to resolve a conflict with a neighbor in my rural field site in 2001 , I encountered a similar result. Although the neighbor was found guilty by the hearing and assessed a list of restitutions to give me, he did not complete any of these tasks. As someone with kinship ties in the community, a permanent rather than temporary resident, a genocide survivor with kin ties to the current as well as the former bourgmestre, and a husband-man (umugabo), he had greater power within the community than I did, so he was not forced to comply with the decisions of the gacaca. This outcome was a surprise to no one but me.

Legal Gacaca appears to be operating in much the same way in communities around Rwanda. In places where inyangamugayo have legitimacy and power within the community, and when they have the will to carry out trials according to legal procedures, Gacaca is working well. However, in most places where the inyangamugayo have little or no power, or where the power brokers in the community seek other ends than fair genocide trials, Gacaca is serving other means and is leading to many injustices.

\section{The Implications of Injustice}

In the short term, Gacaca has destabilized Rwanda and the Gacaca courts have become arenas where local power relations work themselves out under the guise of national policy. The central government is well aware of these destabilizing effects. In early 2007, President Kagame announced that all Gacaca trials should be concluded by the end of the year; in many communities, Gacaca hearings were held up to three days a week in an effort to finish by the president's deadline ${ }^{67}$ In some rural communities, 
residents complained that their families would go hungry because they did not have enough time to tend their fields. ${ }^{68}$ By the end of 2007, Gacaca trials had concluded in many communities, but in others the Gacaca courts continued the work to "close" their files, ${ }^{69}$ and approximately 77,000 accused of Category 1 genocide crimes still awaited trial before the formal court system. ${ }^{70}$ In April 2007, the Rwandan Parliament was considering an amendment to the Gacaca law to allow prosecution of people accused of Category 1 genocide crimes by the Gacaca courts. $^{71}$ It appeared that this amendment would pass with little controversy; as a result, Gacaca could conceivably continue for several more years. Many Rwandans view this expansion of the Gacaca courts' mandate as a source of continued instability and of "opportunistic" accusations and prosecutions. $^{72}$

Gacaca has not only deepened the cleavages between Hutu and Tutsi but also made some Tutsi genocide survivors increasingly mistrustful of the current government and of the RPF. In December 2007, Benoit Kaboyi, executive secretary of Ibuka, addressed an extraordinary congress of genocide survivors' associations and said, "The goal of the gacacas was not to parade people before the courts for form, but to try them well!"73 Despite growing criticism, including some public comments such as these, the government of Rwanda has continued to support the policy. In reaction to statements made by Ibuka, the minister of justice, Tharcisse Kargugarama, vigorously defended the Gacaca courts, stating that "all Rwandans should be delighted ... Those who see things differently are people that are never satisfied."74

Hutu who protected Tutsi during the genocide are facing enormous difficulties. In Gacaca hearings, their acts of heroism are met with suspicion and scrutinized for veracity. If they hid Tutsi in their house for days or weeks but then left them behind to flee the advancing conflict between the RPF and the FAR, they risk being deemed accomplices to the genocide by the inyangamugayo, especially if those Tutsi ended up dead. ${ }^{75}$ Furthermore, they endure discrimination in daily life, where having connections to power (un piston) is a prerequisite for access to a job. On the other hand, they face criticism from those Hutu who supported the Hutu extremists and the genocide: "We told you they [the Tutsi] would subjugate Hutu as they did under the monarchy."76

If these conditions were short-term problems, Gacaca could, perhaps, still be the basis for reconciliation, one of the government's key objectives, as stated in the law and in speeches by government officials. Unfortunately, given local perceptions of widespread injustice in the Gacaca process, the long-term prospects for a peaceful and just society are not positive. Since the Gacaca courts do not have legitimacy in the eyes of the population, they are viewed as merely another imposition of the central government on local communities and another venue in which local power conflicts can work themselves out while appearing to conform to central government policies.

\section{Notes}

1. Lars Waldorf, "Mass Justice for Mass Atrocity: Rethinking Local Justice as Transitional Justice," Temple Law Review 79, 1 (2006): 1-87, 3.

2. I use Gacaca (capitalized) to refer to the Gacaca courts instituted to adjudicate genocide cases and gacaca (lower-case) to refer to the informal, traditional conflict-resolution mechanism.

3. For the number of accused see Filip Reyntjens, "Chronique politique du Rwanda et du Burundi, 2003-2005," L'Afriques des Grands Lacs, Annuaire 2004-2005 (2005): 1-26, 3; for the total number of cases see Felin Gakwaya, "Inkiko Za Gacaca Zimaze Guca Imanza 
Zirenga Ibihumbi 700," BBC Great Lakes.com (3 December 2007), http://www.bbc.co.uk/ greatlakes/news/story/2007/12/071203_gacacacourts.shtml (accessed 15 May 2008).

4. "Kagame Speaks on the Eve of the Launch of Gacaca Trials" (BBC interview), Rwandan government Web site, http://www.gov.rw/government/president/interviews/2001/gacaca. html (accessed 14 September 2007). The original law that established the Gacaca Courts cited similar purposes:

Considering that such offences [genocide and crimes against humanity] were publicly committed before the very eyes of the population, which thus must recount the facts, disclose the truth and participate in prosecuting and trying the allege perpetrators; Considering that the duty to testify is a moral obligation, nobody having the right to get out of it for whatever reason it may be ... Considering the necessity, in order to achieve reconciliation and justice in Rwanda, to eradicate for good the culture of impunity and to adopt provisions enabling to ensure prosecutions and trials of perpetrators and accomplices without only aiming for simple punishment, but also for the reconstitution of the Rwandese society made decaying by bad leaders who prompted the population to exterminate one part of that society; Considering that it is important to provide for penalties allowing convicted prisoners to amend themselves and to favour their reintegration into the Rwandese society without hindrance to the people's normal life ...

Preamble, Organic Law No 40/2000 of 26/01/2001 setting up "Gacaca Jurisdictions" and Organizing Prosecutions for Offences Constituting the Crime of Genocide or Crimes against Humanity Committed between October 1, 1990 and December 31, 1994.

5. As a Bantu language, Kinyarwanda uses prefixes to indicate the part of speech of a word and whether it is singular or plural (uMuhutu/aBahutu, uMututsi/aBatutsi, uMutwa/ $a B a t w a)$. In my usage in this article, I have removed the prefixes but do not further anglicize the terms "Hutu," "Tutsi," and "Twa" when using them as nouns by adding an $s$ to the plural. This practice reflects Rwandans' own usage of these terms in English and French and attempts to undermine the (mistaken) notion that these labels apply to corporate groups.

6. In October 1990, the Rwandan Patriotic Front (RPF), a rebel movement composed predominantly of Tutsi living in exile, attacked Rwanda with the intention of liberating the country from the dictatorship of President Juvénal Habyarimana. The resulting civil war continued throughout the early 1990s and shaped the emerging rhetoric of ethnic hatred on the part of the Hutu extremists who held the reins of power. In 1993, the RPF, Habyarimana, and opposition political parties signed the Arusha Peace Accords, which called for a power-sharing arrangement. When the genocide began, following the shooting down of President Habyarimana's plane on the evening of 6 April 1994, the RPF resumed its military campaign against the Forces Armées Rwandaises (FAR) the Rwandan army. The genocide came to an end when the RPF seized the majority of the territory in July 1994.

7. Organic Law No 08/96 of August 30, 1996 on the Organization of Prosecutions for Offences Constituting the Crime of Genocide or Crimes against Humanity Committed since October 1, 1990.

8. Organic Law $\mathrm{N}^{\circ}$ 40/2000 of 26/01/2001; Organic Law $\mathrm{N}^{\circ}$ 16/2004 of 19/6/2004 establishing the Organisation, Competence and Functioning of Gacaca Courts Charged with Prosecuting and Trying the Perpetrators of the Crime of Genocide and Other Crimes against Humanity Committed between October 1, 1990 and December 31, 1994; Organic Law $\mathrm{N}^{\circ} 10 / 2007$ of 01/03/2007 modifying Law $\mathrm{N}^{\circ} 16 / 2004$; Organic Law $\mathrm{N}^{\circ}$ 28/2006 of 27/06/2006 modifying Law $\mathrm{N}^{\circ} 16 / 2004$; Organic Law $\mathrm{N}^{\circ}$ 08/2004 of 28/04/2004 on the Establishment, Organization, Duties and Functioning of the National Service in Charge of the Follow-Up, Supervision and Coordination of the Activities of Gacaca Jurisdictions.

9. UN Security Council Resolution 955, UN Doc. S/RES/955 (8 November 1994). 
10. Trial Watch, “Jean-Paul Akayesu," http://www.trial-ch.org/en/trial-watch/profile/db/legalprocedures/jean-paul_akayesu_160.html (accessed 15 May 2008).

11. These opinions were expressed in interviews conducted by the author in various locations in Rwanda in 1999, 2000, 2001, 2002, 2003, and 2007. Until July 2007, Rwanda still retained the death penalty, which was the punishment for those found guilty of Category 1 crimes (including planning and directing the genocide) under the "genocide code." In addition, people awaiting trial at the ICTR stay in air-conditioned cells with access to an exercise room, television, and the Internet, whereas detainees in Rwanda generally face miserable living conditions and lack adequate food and water.

12. As of June 2006, the ICTR had completed the prosecution of twenty-eight defendants, twenty-five of whom were found guilty and three acquitted. ICTR, "Achievements of the ICTR," http://69.94.11.53/ENGLISH/factsheets/achievements.htm (accessed 15 September 2007).

13. "Rwandan Is First to Stand Trial in Canada under War Crimes Act," International Herald Tribune, 26 March 2007, http://www.iht.com/articles/ap/2007/03/26/america/NA-GENCanada-Rwandan-Genocide.php (accessed 15 September 2007).

14. "The Munyaneza Trial Will Go to Europe and Rwanda," Hirondelle News Agency, 10 October 2007, http://www.hirondellenews.com/content/view/1093/459/ (accessed 15 May 2008); "Trial of Desiré Munyaneza Set to Enter Second Year," Hirondelle News Agency, 11 March 2008, http://www.hirondellenews.com/content/view/1704/497 (accessed 20 May 2008).

15. See, for example, "Rwanda Urges Canada to Extradite 'Genocide Masterminds," CBC News, 31 August 2007, http://www.cbc.ca/world/story/2007/08/31/rwandan-extradition. html (accessed 15 September 2007).

16. Human Rights Watch [HRW], World Report 2002 (New York: HRW, 2002), 79.

17. Filip Reyntjens, "Le Gacaca ou la justice du gazon au Rwanda," Politique Africaine 40 (1990): 31-41.

18. Jyoni wa Karega, Philbert Kagabo, Abbe Smaragde Mbonyintege, Jean Chrisostome Munyampirwa, and Ladislas Twahirwa, Gacaca: le droit coutumier au Rwanda (Kigali: Nations Unies, Haut commissaire aux droits de l'homme, Operation sur le terrain au Rwanda, 1996).

19. Timothy Longman, conversation with the author, April 2007.

20. See Penal Reform International, Monitoring and Research Report on the Gacaca \#8: Information-Gathering During the National Phase (London: Penal Reform International, 2006), 26-37. Article 14 of the International Covenant on Civil and Political Rights, 16 December 1966, 999 U.N.T.S. 171, http://www.unhchr.ch/html/menu3/b/a_ccpr.htm (accessed 15 May 2008), outlines the fundamental rights every person accused of a crime shall have before the law.

21. Peter Uvin and Charles Mironko, "Western and Local Approaches to Justice in Rwanda," Global Governance 9 (2003): 219-31, 227.

22. See Organic Law No 16/2004 of 19/6/2004, chapter IV, arts. 72-5, and Organic Law No. $40 / 2000$ of $26 / 01 / 2001$, chapter 4 , arts. $68-71$.

23. These views were expressed in interviews with the author in various locations in Rwanda in 2001 and 2002.

24. HRW, World Report 2002.

25. HRW, "Rwanda-Human Rights Overview," http://hrw.org/english/docs/2006/01/18/ rwanda12286.htm (accessed 18 June 2008); IRIN, "Rwanda: Release of Suspects in the 1994 Genocide Angers Survivors," http://www.irinnews.org/report.aspx?reportid=55758 (accessed 18 June 2008); IRIN, "Rwanda: Release of Thousands of Prisoners Begins," http:// www.irinnews.org/report.aspx?reportid=55647 (accessed 18 June 2008).

26. Hirondelle News Agency, "Rwanda Wants to Relieve Congestion in Prisons," Rwanda Development Gateway, December 6 2007, http://www.rwandagateway.org/ article.php3?id_article=7543 (accessed 16 May 2008).

27. Reyntjens, "Chronique politique," 13. 
28. Gakwaya, "Inkiko Za Gacaca."

29. Martien Schotsman, A l'écoute des rescapés: recherche sur la perception par les rescapés de leur situation actuelle (Kigali: GTZ, 2000); Jennie E. Burnet, "Genocide Lives in Us: Amplified Silence and the Politics of Memory in Rwanda" (PhD diss., University of North Carolina at Chapel Hill, 2005).

30. This information emerged from interviews and ethnographic fieldwork conducted by the author between 1999 and 2007. See also Claudine Vidal, "Les Commémorations du génocide au Rwanda," Les temps modernes 613 (2001): 1-46, 26; Jennie E. Burnet, "Whose Genocide? Whose Truth? Representations of Victim and Perpetrator in Rwanda," in Genocide: Truth, Memory and Representation, ed. Alex Laban Hinton and Kevin O'Neill (Durham: Duke University Press, forthcoming).

31. Anuradha Chakravarty, "Local Dynamics of Contention around Genocide Trials in Rwanda" (paper presented at the African Studies Association Annual Meeting, San Francisco, November 2006), 28-29.

32. Interviews in Rwanda, 2007; personal communication with international human-rights observer, October 2007; HRW, "Rwanda-Human Rights Overview," in World Report 2007(New York: HRW, 2007), http://hrw.org/wr2k8/pdfs/rwanda.pdf (accessed 20 May 2008), 1. For more on partial or untrue confessions in the Gacaca process see Penal Reform International [PRI], PRI Research Gacaca Report \#4: The Guilty Plea Procedure, Cornerstone of the Rwandan Justice System (London: PRI, 2003), 8.

33. Ironically, those who are innocent and have no crimes to confess remain incarcerated while the Gacaca process continues.

34. Reyntjens, "Chronique politique," 13.

35. Interviews in Rwanda, 2007; interviews with Rwandans in the United States, 2006 and 2007.

36. Scott Straus, The Order of Genocide: Race, Power, and War in Rwanda (Ithaca, NY: Cornell University Press, 2006), 136-38.

37. A Rwandan, e-mail message to the author, November 2007.

38. Interviews in Rwanda, 2007; HRW, "Rwanda-Human Rights Overview," 2; Christina M. Carroll, "An Assessment of the Role and Effectiveness of the International Criminal Tribunal for Rwanda and the Rwandan National Justice System in Dealing with the Mass Atrocities of 1994," Boston University International Law Journal 18 (2000): 163-200, 185.

39. Amnesty International, Rwanda: Reports of Killings and Abductions by the Rwandese Patriotic Army, April-August 1994 (New York: Amnesty International, 1994); Alison Des Forges, Leave None to Tell the Story: Genocide in Rwanda (New York: Human Rights Watch, 1999), 702-22.

40. Des Forges, Leave None to Tell the Story, 702.

41. Ibid., 716, citing UNAMIR, Notes, Radio Rwanda, 19:00, July 27, 1994.

42. Rwandan living in the USA, interview with the author, North Carolina, USA, 2002.

43. HRW, "Rwanda-Human Rights Overview"; IRIN, "Release of Suspects"; IRIN, "Release of Thousands."

44. Female respondent, focus group, Southern province, May 2007. The interviews, conversations, and focus groups were conducted in a mixture of French, Kinyarwanda, and English. Unless otherwise indicated, all translations are my own.

45. Female respondent, focus group, Southern province, May 2007.

46. Female respondent (Tutsi, widow of the genocide), focus group, Southern province, June 2007.

47. Female respondent (Tutsi, widow of the genocide), focus group, Southern province, May 2007.

48. Female respondent (Tutsi, widow of the genocide), focus group, Southern province, May 2007.

49. Ibid.

50. Conversation, Western province, May 2007.

51. Ibid. 
52. Focus group, Southern province, June 2007.

53. All names have been changed to protect the identities of informants.

54. Following the RPF victory in July 1994, the military wing of the RPF became the new national army, replacing the FAR, under the name Rwandan Patriotic Army (RPA). In the early 2000s, the RPA again changed its name; it is now known as the Rwandan Defence Forces (RDF).

55. Interview with another community member, Rwanda, 2001.

56. Attendance at Gacaca is a compulsory civic duty. On days when Gacaca is held, all businesses, schools, and offices close so that everyone can attend. Citizens who are absent from Gacaca face fines and even imprisonment.

57. Burnet, "Genocide Lives in Us," 12-174; Burnet, "Whose Genocide?"

58. I interviewed these women's groups, as well as individual members of them, on numerous occasions from 2000 through 2007. In addition, I conducted one year of ethnographic research in the community where they were located.

59. Focus group, Southern province, May 2007.

60. In this statement "pastoralists" can be read as "Tutsi" and "farmers" as "Hutu." Many of the Tutsi living in rural areas of Northern province are predominantly cattle herders with only small garden plots, while the Hutu usually have comparatively large fields and keep only one or two cows and smaller livestock. Many of these "Tutsi" pastoralists are actually Bagogwe, who historically were distinct from Tutsi but had come to be considered Tutsi by the late 1980s.

61. In this context, "fifty-niners" are the predominantly Tutsi refugees who returned to Rwanda following the RPF victory in 1994. Many of these refugees left Rwanda in 1959, when mass violence targeted members of the Tutsi nobility, or were descendants of those who left in 1959.

62. Focus group, Northern province, June 2007.

63. "Ibuka critique les jugements gacacas," Hirondelle News Agency, 6 December 2007, http:// www.africatime.com/rwanda/nouvelle.asp?no_nouvelle=367013\&no_categorie $=2$ (accessed 16 May 2008).

64. Jennie E. Burnet and Rwanda Initiative for Sustainable Development [RISD], "Culture, Practice, and Law: Women's Access to Land in Rwanda," in Women and Land in Africa: Culture, Religion and Realizing Women's Rights, ed. Lynne Muthoni Wanyeki, 176-206 (New York: Zed Books, 2003); Dorothea Hilhorst and Mathijs van Leeuwen, Imidugudu, Villagisation in Rwanda: A Case of Emergency Development (Wageningen: Disaster Studies, 1999); HRW, Uprooting the Rural Poor in Rwanda (New York: HRW, 2001); Chantal Laurent and Christian Bugnion, External Evaluation of the UNHCR Shelter Program in Rwanda 1994-1999 (Geneva: UNHCR, Reintegration and Local Settlement Section, 2000); Herman Musahara, "Villagisation and Land Use in the Context of the Rwandan Economy" (paper presented at the Land Use and Villagisation Workshop, Kigali, 20-21 September 1999); RISD, "Land Use and Villagisation in Rwanda" (paper presented at the Land Use and Villagisation Workshop, Kigali, 20-21 September 1999).

65. Focus group, Northern province, June 2007.

66. Pierre Bettez Gravel, Remera: A Community in Eastern Rwanda, ed. Kathleen M. Stahl (The Hague: Mouton, 1968), 170-85.

67. Interviews, Rwanda, May and June 2007.

68. Ibid.

69. "Gacaca Trials Could Continue in 2008," Hirondelle News Agency, 21 November 2007, http://allafrica.com/stories/200711220365.html (accessed 17 June 2008).

70. "Towards a New Amendment of the Gacaca Law," Hirondelle News Agency, 5 December 2007, http://www.hirondellenews.com/content/view/1316/309/ (accessed 16 May 2008).

71. James Buyinza, "Gacaca Draft Law Goes to Senate," New Times, 17 April 2008, http://www.newtimes.co.rw/print.php?issue $=13503 \&$ print\&article $=5627$ (accessed 17 June 2008). 
72. E-mail communications and conversations with Rwandans living in the United States, May 2008.

73. "Ibuka Draws Up a Negative Assessment of the Gacaca Courts," Hirondelle News Agency, 11 December 2007, http://allafrica.com/stories/printable/200712120624.html (accessed 19 December 2007).

74. "The Rwandan Government Refutes Criticism by Ibuka," Hirondelle News Agency, 12 December 2007, http://www.hirondellenews.com/content/view/1354/291/ (accessed 19 June 2008).

75. Interview, Kigali, June 2007.

76. E-mail communication from recent Rwandan exile, December 2007. 